\title{
ROLE OF DIMETHYL SULFATE ON BIOCHEMICAL CHARACTERISTICS OF Fragaria ananassa Duch UNDER SALINITY STRESS IN VITRO
}

\author{
Yasir S. S. \\ R. M. Hamad* \\ S. I. Neamah ${ }^{* *}$ \\ Lecturer \\ Prof. \\ Assist. Prof.
}

*Dept.Horticulture and Landscape Architecture, University of Anbar, Iraq.

***Pant Tissue Culture Lab., Center of Desert Studies, University of Anbar, Iraq.

***-mail: ds.dr.shamil@uoanbar.edu.iq

\section{ABSTRACT}

The aims of this study were to evaluate the effect of four concentrations of Dimethylsulfate (DMS) $0 \%, 0.03 \%, 0.06 \%$ and $0.1 \%$ under four levels of salinity including $0,30,60$ and 90 mmol $\mathrm{NaCl} \mathrm{L} \mathrm{L}^{-1}$ on some biochemistry characters such as proline, hydrogen peroxide $\left(\mathrm{H}_{2} \mathrm{O}_{2}\right)$, catalase (CAT), superoxide dismutase (SOD), chlorophyll a (Chl $a)$, chlorophyll b $(\mathrm{Chl} b)$ and total chlorophyll. All treatments were distributed according to the factorial experiment using complete ro(CRD) with five replicates. Results revealed that $0.03 \%$ of DMS gave the highest proline of $2.08 \mathrm{mg} \mathrm{g}^{-1}, \mathrm{H}_{2} \mathrm{O}_{2}$ of $0.64 \mu \mathrm{M} 100 \mathrm{mg}^{-1}$, catalase of $19.53 \mathrm{AU} \mathrm{min} \mathrm{m}^{-1}$ and SOD of 116.8 IU 100 $\mathrm{mg}^{-1}$. The control achieved the highest Chl $a$ of35.75 $\mathrm{mg} \mathrm{g}^{-1}, \mathrm{Chl} b$ of $23.38 \mathrm{mg} \mathrm{g}^{-1}$ and total chlorophyll of $79.00 \mathrm{mg} \mathrm{g}^{-1}$. Furthermore, $30 \mathrm{mM} \mathrm{NaCl} \mathrm{L}^{-1}$ possesses highest proline of $2.14 \mathrm{mg} \mathrm{g}^{-1}, \mathrm{H}_{2} \mathrm{O}_{2}$ of $0.62 \mu \mathrm{M} 100 \mathrm{mg}^{-1}$, catalase of $19.38 \mathrm{AU} \mathrm{min}^{-1} \mathrm{~g}^{-1}$ and SOD of 114.0IU 100 $\mathrm{mg}^{-1}$. The non-saline plantlets (control) gave highest Chl.a of $33.00 \mathrm{mg} \mathrm{g}^{-1}$, Chl $b$

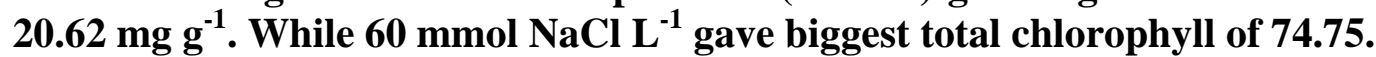

Key word: plant tissue culture, strawbwrry, chemical mutagen, sodium Chloride.

صخي وأخرون

مجلة العلوم الزراعية العراقية -121-111:53:2022 (1) مجاعة

دور dimethylsulfate في الصفات الكيموحيوية للفراولة Fragaria ananassa Duch تحت الأجهاد الملحي خارج
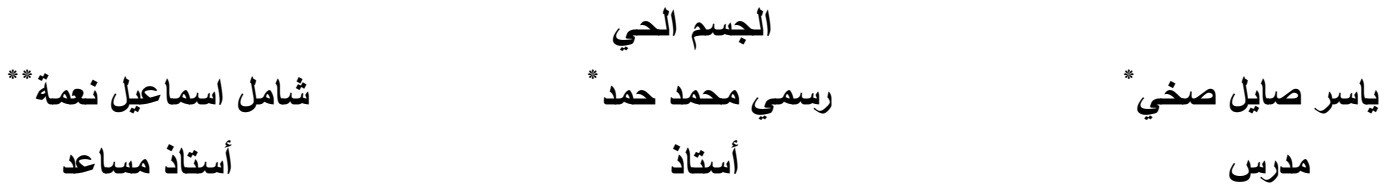

"قسم البستنة وهندسة الحدايق، كلية الزراعة، جامعة الانبار، العراق.

“"مختبر زراعة الأنسجة النباتية, مركز دراسات الصحراء، جامعة الانبار ، العرلق.



هدفت الدراسة الحالية اختبار تاثير اريعة تراكيز من dimethyl sulfate وهي 0 و 0.03\% و 0.06\% و 0.1\% م 0.

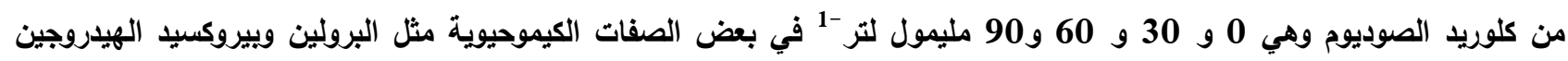
وانزيم catalase و أنزيم superoxide dismutase و وكلوروفيلa و كلوروفيلb و والكلوروفيل الكلي. أظهرت النتائج تفوق التركيز

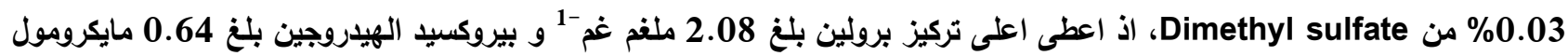

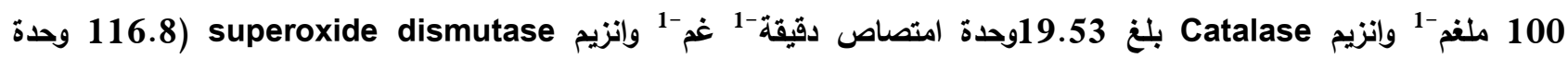

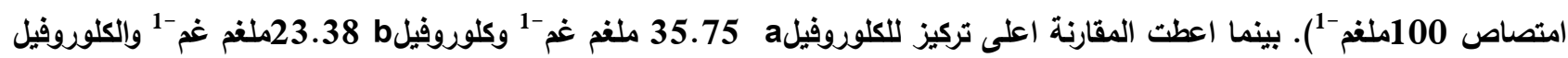

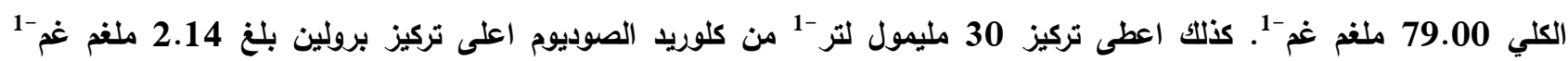

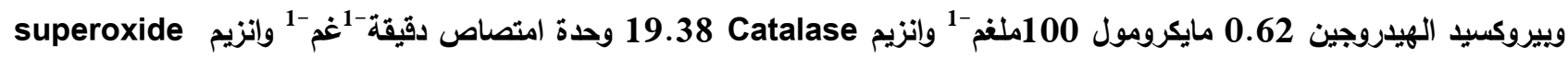



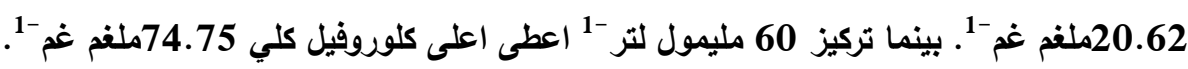
الكلمات المفتاحية: زراعة انسجة، الفزاولة، مطفر كيميائي، كلوريد الصوديوم 


\section{INTRODUCTION}

Strawberry (Fragaria ananassa Duch) is one of the most important small fruits of the Rosaceae family, which is economically consumed due to its content of elements and its desired taste (27). The reason for the increase in global consumption of the very high fruit of strawberry is because of its antibacterial, anti-fungal and antioxidant properties, and it also resulted in the increased release of many secondary metabolites from this plant (11). Strawberry is being a good source of compounds possessing antioxidant properties of natural origin, it contains compounds such as carotenoids, vitamins, phenols, flavonoids, and glutathione, as it is believed to reduce the incidence of cancer diseases $(18,26)$. The exacerbation of the problem of salinity in agricultural lands is one of the most specific problems of agricultural production, as more than $20 \%$ of those lands in dry and semi-arid regions, including Iraq, have been negatively affected by this issue. Traditional irrigation, the use of highly saline irrigation water and the excessive use of chemical fertilizers contributed to a gradual accumulation of salts in the root zone and the surface of the soil, many in vivo studies had applied to improve growth and yield of strawberry over Iraqi environment (10), especially cv. Festival (17). However, in vitro trials were very limited that studied the tolerance of this crop to salinity stress. Thus becoming unfit for agriculture due to increased osmosis and imbalance of nutrients and toxicity as well as their effects. Tissue culture is an important technology for mutation induction and for inducing genetic variation and selection at the cell level in traits that he wants to improve for several crops by cultivating plants, cells and plant tissues. The development of mutations is an effective tool for developing new genetic material in plant species, especially when exposed to different stresses (29). Mostafa (22) noted that dipping Khaya seeds with chemical mutants such as Dimethyl sulphate (DMS) and NaN3 in several concentrations for 15 hours led to the improvement of growth characteristics and increased content of alkaloids in leaves. Dimethyl sulphate led to dwarfing of plants in the second season and the color of the stem to red, attributing the reason for a mutation as a result of using these chemicals. In the study conducted by Murti et al. (25) which used Ethyle methane sulphonate (EMS) on the mutagenesis of strawberry plants in vitro trial, there are plants with thicker leaves and larger pollen grains as a result of the treatment of Ethyle methane sulphonate and this difference increased when using Gamma rays with a chemical mutagen. Adak and Kaynak (1) stated Treatment of strawberry plants with concentrations of Ethyle methane sulphonate $(0,0.2,0.4,0.6$ and $0.8 \%)$ for 60,90 and 120 minutes. It reduced survival time, number of mites, number of roots, length of stems, and number of leaves while, the best treatment of Ethyle methane sulphonate was $0.4 \%$ for 60 minutes, and for multiplication and rooting $0.2 \%$ for 60-90 minutes. Mutagen concentrations Dimethyl sulphate have important effects that cause changes in subsequent generations as a result of mutations. It was found that the concentration of $600 \mathrm{mg}$ of Dimethyl sulphate has a stimulating effect on all the vegetative growth characteristics of Tecoma plants for the first generation individuals while the concentration of 200 and $1000 \mathrm{mg}$ increased the number of florets in the flower (19). Studies by Vasko and Kyrychenko (34) show the importance of Dimethyl sulphate that was the most effective chemical mutagen in causing genetic variation in plants. It observed the appearance of phenotypic differences in some plant traits, as well as the increase in seed oil, seed weight and fatty acid content. Treatment of plants with Dimethyl sulphate reduced the fatal effect of salt tension, two mutants were found superior to the comparison under salt tension with a concentration ranging from 1000-2000 $\mathrm{mg}$, increase in the activity of the enzyme Catalase and an increase in carotenoids and sodium were observed (20). The treatment of plants with a solution of Dimethyl sulphate at a concentration of $0.05 \%$ led to a slight decrease in the plant and the occurrence of changes in the color of the growing apex in yellow as well as the radial flowers and the characteristic of multiple heads and the reduction of the number of leaves, which leads to a reduction in the rate of photosynthesis and also appeared multiple-leaf strains 85_91 leaf ${ }^{-1}$ 
in the sunflower plant (32). Exposing strawberry plants to abiotic stress (saline) at a concentration of $50 \mathrm{mmol}$ reduced the activity of SOD and CAT enzymes, but increased the POD enzyme, and treating them with Sodium nitroprusside (SNP) at a concentration of 0.1 led to a difference in the activity of these enzymes, which caused a decrease in the adverse effects of slat tension in Strawberry (16). Surveys such as that conducted by Mozafar et al. (23) have shown that in vitro treatment of strawberry with 3 concentrations of salt tension $(0,50$ and $100 \mathrm{mmol} \mathrm{NaCl})$ caused negative effects on growth, carotenoid content, relative water content, ionic disturbance in mature plants and evidence of plant membrane stability. Hussein et al., (13) documented adding sodium chloride to the culture medium of strawberries at levels of 500, 750 and $1000 \mathrm{mg} \mathrm{L}^{-1}$ reduced the chlorophyll content $(10.13 \mathrm{mg} / \mathrm{g})$, the plumule length of $2.10 \mathrm{~cm}$, the dry weight of the plumule $1.22 \mathrm{mg}$, the length and dry weight of the radical $0.96 \mathrm{mg}$ These results may indicate selection for salt tolerance of strawberry plants using tissue culture method. Jamalian et al. (15) stated Treatment of strawberry plants with saline concentrations for 5 weeks and also a salt shock at a concentration of 20 mmol liters 1 found an increase in caffeic acid and coumaric acid and an increase in ferulic acid under saline shock at different levels of salt stress, which are indicators of salt tolerance and a way of defense for the production of antioxidant compounds. Zahedi et al. (35) showed in their study using salinity levels $(0$, 40 , and $80 \mathrm{mmol} \mathrm{NaCl}$ ) on strawberry plants under salt stress reduced the yield and increased the oxidative stress and quality of the fruit. This study aimed to investigate the effect of chemical mutagens in the development of genetic variants of the species of Albion and compare its behavior under different levels of salt tension outside the plant body by studying some of the physiological and biochemical mechanisms, as well as determining the genetic variances that occur in the species under study using some molecular indicators.

\section{MATERIALS AND METHODS}

The experiment was carried out in the Tissue Agriculture Laboratory of the Desert Studies
Center/ University of Anbar for the year 20192020 when seedlings were brought from the city of Heet in Anbar for the Albion species, this species was distinguished by its quality and excellent production. The separated stolons were transferred from the field to the laboratory, the top of the stolon was cut to a length of approximately $1 \mathrm{~cm}$ (14). The stolon was thoroughly cleaned with liquid soap, rinsed with running water for an hour, and then transferred to the Laminar airflow cabinet for sterilization.

Sterilization of tools and plant parts: Metal and glass work supplies, which included surgical blade holders, tweezers, Petri dishes, beakers and flasks, were sterilized after washing them with water and detergents, then washed with distilled water and then placed in the oven at a temperature of $200{ }^{\circ} \mathrm{C}$ for two hours (2). Distilled water was sterilized in an Autoclave at $121^{\circ} \mathrm{C}$ and pressure at $1.04 \mathrm{~kg}$ $\mathrm{cm}^{-2}$ for 15 minutes. The plant parts were surface sterilized by immersing them in a Clorox solution consisting of sodium hypochlorite at a concentration of $6 \%$ (volume weight ${ }^{-1}$ ) after it was diluted to a concentration of $3 \%$ (volume weight ${ }^{-1}$ ) of the sterilization solution with the addition of a few drops of Tween 20 diffuser to reduce its surface tension, and then immersed in ethanol at a concentration of $70 \%$ for one minute, after that washed the plant parts with water three times for five minutes, after which the plant parts were transferred to sterile Petri dishes for removing the top of the stolon Runner tip $0.5 \mathrm{~cm}$ long and separated using sterile scalpels and tweezers.

Medium preparation: Standard MS medium (24) provided by Caisson company was used, then $30 \mathrm{~g} \mathrm{~L}^{-1}$ of sucrose was added and then the necessary growth regulators were added according to the experiment requirements. Add $1 \mathrm{~mL}$ of PPM (Plant Preservative Mixture) to reduce fungal and bacterial contamination (28). Also, add activated charcoal at a concentration of $4.0 \mathrm{~g} \mathrm{~L}^{-1}$ and adjust the $\mathrm{pH}$ to 5.7-5.8 with $\mathrm{NaOH}$ or $\mathrm{HCl}$, then add $7.0 \mathrm{~g} \mathrm{~L}^{-1}$ agar to the medium. Then completed the volume to 1 liter and then melt by heating on a magnetic stirrer a hot plate to a boil. The prepared medium was distributed in a Vials volume of $10 \mathrm{ml}$. The bottles were covered 
with their covers, then sterilized with pressure and steam at $1.04 \mathrm{~cm}^{-2} \mathrm{~cm}$ and $121^{\circ} \mathrm{C}$ for 20 minutes respectively. The test tubes were left closed in the growth chamber until they are used.

Stage of growth of implants and multiplication: At this stage, the growing apex of the cultivar understudy is grown in MS medium prepared with a concentration of 0.5 $\mathrm{mg} \mathrm{L}^{-1}$ of BA growth regulator with $0.1 \mathrm{mg} \mathrm{L}^{-1}$ of IBA growth regulator and incubated at a temperature of $24^{\circ} \mathrm{C} \pm 1$ and a brightness of 1000 lux for a light period. The amount of 16 hours versus 8 hours of darkness for four weeks. The branches resulting from the previous stage (phylogenetic stage) of the cultivar under study were transferred to the medium of multiplication, which is an MS medium prepared with concentrations of 1.0 $\mathrm{mg} \mathrm{L}^{-1}$ of BA growth regulator with an addition of $0.1 \mathrm{mg} \mathrm{L}^{-1}$ of IBA growth regulator with the same conditions referred to in the previous paragraph.

Chemical treatments: Three concentrations of DMS were also prepared by preparing 3 concentrations of the mutagen solution $(0.03$, 0.06 and $0.1 \%$ ), and then the $\mathrm{pH}$ was adjusted for the levels of the previously mentioned solutions to 7.2 because it greatly affects the ratio of genetic mutations to the chromosome (31). The mutagenic solutions were placed in sterile bottles and the solutions were sterilized by autoclave at a pressure of $1.04 \mathrm{~kg} \mathrm{~cm}^{-2}$ and at a temperature of $121^{\circ} \mathrm{C}$ for 20 minutes to treat the plants with them. The plants were completely immersed in the solution of each concentration for one hour in a laminar airflow cabinet. Then it was removed and washed with sterile distilled water for 10 minutes with shaking 3-5 times. After that, it was planted on the growth medium (MS) at the same concentrations as shown in the stage of plant growth for one month.

Exposing plants to salt stress: The MS culture medium was prepared with the same concentrations shown in the process of plant growth, then three salt concentrations of $\mathrm{NaCl}$ were added to it $(0,30,60$ and $90 \mathrm{mmol})$ each according to its treatment. After preparing the treatments, the plants were planted on the culture medium to which the salt concentrations were added and left to grow for 6 weeks. This experiment was carried out with five replications, each vegetative growth is an experimental unit, and then the growth data were recorded.

Measured indicators: Data were recorded on the total concentration of proline, $\mathrm{H}_{2} \mathrm{O}_{2}, \mathrm{CAT}$, SOD, Chl $a$ and $b$., and total Chlorophyll. A factorial experiment was applied using a completely randomized design for all measured indicators, then its data were statistically analyzed by managing the lowest significant difference test and at probability level 0.05 (5) the data set to the electronic statistical program Genstat version (12).

\section{RESULTS AND DISCUSSION}

\section{Proline concentration $\left(\mathrm{mg} \mathrm{g}^{-1}\right)$}

Table 1 shows that the mutagen levels differed significantly among treatments, level $0.03 \%$ appeared the highest concentration of proline acid, which reached $2.08 \mathrm{mg} / \mathrm{g}$, then the level $0.1 \%\left(2.01 \mathrm{mg} \mathrm{g}^{-1}\right)$, so the level was $0.06 \%$ $\left(1.82 \mathrm{mg} \mathrm{g}^{-1}\right)$, while the comparison treatment showed 1.44. $\mathrm{mg} \mathrm{g}^{-1}$ of proline. However, it is noticed from the table that there were significant differences between salinity levels in the concentration of proline, the level 30 mmol liter ${ }^{-1}$ that revealed the highest concentration of proline at $2.14 \mathrm{mg} \mathrm{g}^{-1}$, then the level 90 mmol liter ${ }^{-1}\left(1.97 \mathrm{mg} \mathrm{g}^{-1}\right)$, followed by the comparison treatment (1.66 $\mathrm{mg} \mathrm{g}^{-1}$ ), while the $60 \mathrm{mmol}$ levels showed the lowest proline concentration of $1.57 \mathrm{mg} \mathrm{g}^{-1}$. Table 1 reveal there were significant differences between the two interactions in the concentration of proline. An interaction of $0.1 \%$ of the mutagen $\mathrm{X} 30 \mathrm{mmol}^{-1}$ of sodium chloride appeared the highest concentration of $2.71 \mathrm{mg} \mathrm{g}^{-1}$, followed by an overlap between $0.03 \%$ x $90 \mathrm{mmol} \mathrm{L}^{-1}$ of $\mathrm{NaCl}$ and $2.70 \mathrm{mg} \mathrm{g}^{-1}$. While the interaction presented $0.06 \%$ of the mutagen $\mathrm{X} 60 \mathrm{mmol} \mathrm{L}^{-1}$ of $\mathrm{NaCl}^{-1}$ of sodium chloride, the lowest concentration was $1.40 \mathrm{mg}$ $\mathrm{g}^{-1}$. 
Table 1. Effect of chemical mutagens DMS on average proline of strawberries under saline stresses an in vitro

\begin{tabular}{|cccccc|}
\hline Mutagen & \multicolumn{5}{c|}{ Salinity levels (mmol) } \\
DMS $(\%)$ & 0 & 30 & 60 & 90 & Mean \\
\hline 0 & 1.45 & 1.41 & 1.43 & 1.46 & 1.44 \\
0.03 & 1.84 & 1.88 & 1.92 & 2.70 & 2.08 \\
0.06 & 1.42 & 2.57 & 1.40 & 1.88 & 1.82 \\
0.1 & 1.95 & 2.71 & 1.52 & 1.86 & 2.01 \\
Mean & 1.66 & 2.14 & 1.57 & 1.97 & \\
LSD p $\leq$ 0.05 & DMS $=\mathbf{0 . 0 2}$ & Salt. $=\mathbf{0 . 0 2}$ & DMS $\times$ Salt. $=\mathbf{0 . 0 4}$ \\
\hline
\end{tabular}

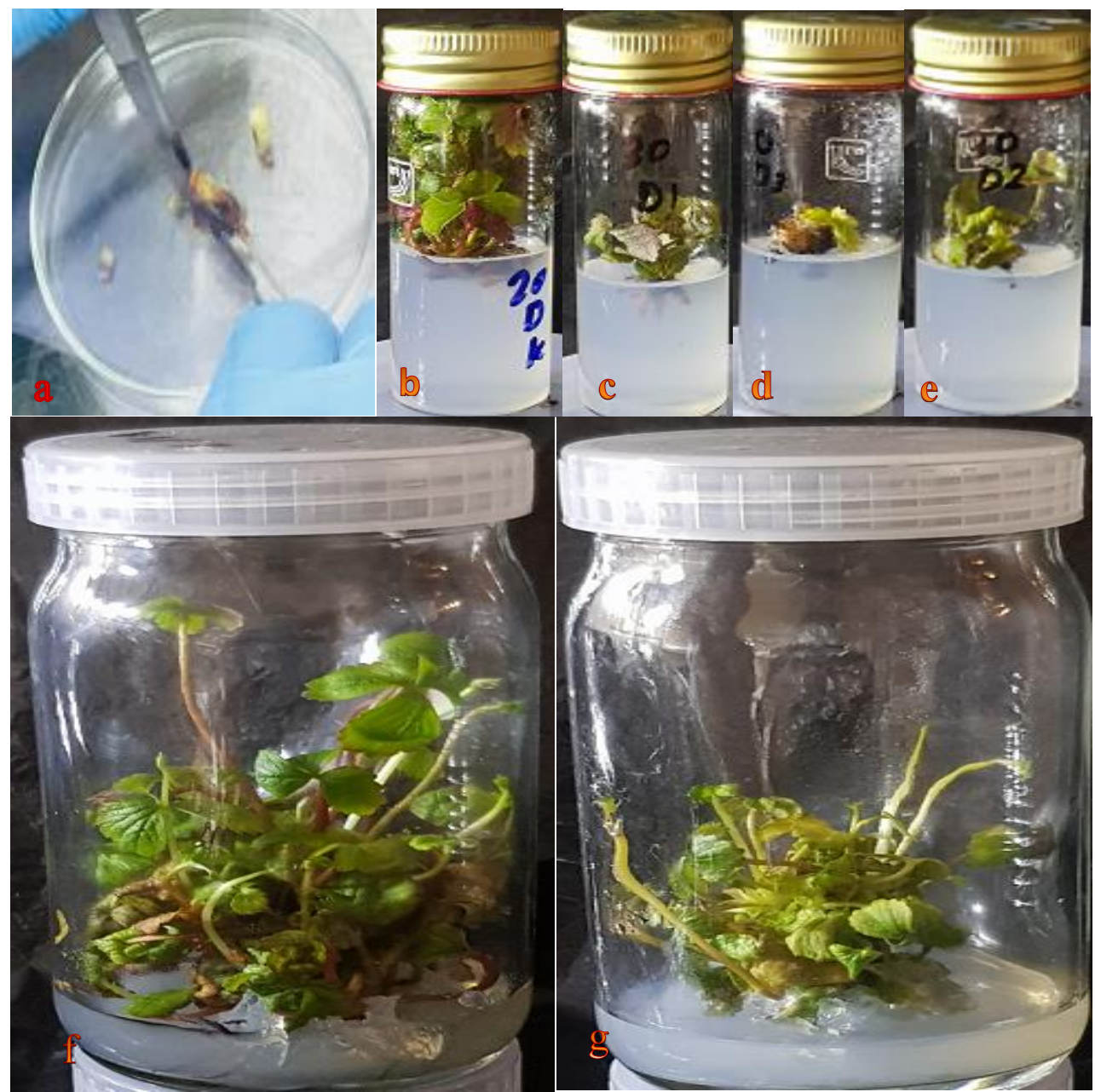

Figure 1. Experimental $F$. ananassa Duch microshoot the appearance of biomasses depending on the applied DMS concentrations and the levels of salinity used. (a) The explant used. (b) 0 mmol salinity and $0.03 \%$ DMS. (c) 90 mmol salinity and $0.03 \%$ DMS. (d) 90 mmol salinity and $0.06 \%$ DMS. (e) 90 mmol salinity and 0.1 \% DMS. (f and g) Micropropagation of $F$. ananassa Duch in advanced stages

Hydrogen peroxide concentration ( $\mu$ mol the results that there were significant $100 \mathrm{mg}^{-1}$ D.W)

Table 2 shows that the mutagen levels differed significantly across treatments, the level $0.03 \%$ was the highest concentration of hydrogen peroxide, which was $0.64 \mu \mathrm{mol} 100$ $\mathrm{mg}^{-1}$ D.W, then the level $0.1 \%(0.61$ micromol $100 \mathrm{mg}^{-1}$ D.W), the level $0.06 \%$ $\left(0.54\right.$ micromol $\left.100 \mathrm{mg}^{-1} \mathrm{D} . \mathrm{W}\right)$ while the control treatment was $\left(0.43\right.$ micromol $100 \mathrm{mg}^{-}$ ${ }^{1}$ D.W) of hydrogen peroxide. It is noted from differences between salinity levels in the concentration of hydrogen peroxide. The level was $30 \mathrm{mmol} \mathrm{l}^{-1}$ showed the highest concentration of hydrogen peroxide 0.62 micromol $100 \mathrm{mg}^{-1} \mathrm{D} . \mathrm{W}$, then the level 90 mmol $\mathrm{l}^{-1}\left(0.61\right.$ micromol $100 \mathrm{mg}^{-1}$ D.W $)$ for control treatment $\left(0.50\right.$ micromol $100 \mathrm{mg}^{-1}$ D.W), while the $60 \mathrm{mmol}$ level revealed the lowest concentration of hydrogen peroxide, 0.49 micromol $100 \mathrm{mg}^{-1}$ d.w. From Table 2, it 
was evident that there were significant differences between the interactions of the two factors in the concentration of hydrogen peroxide, as an interaction of $0.03 \%$ of the mutagen $\times 90 \mathrm{mmol}^{-1}$ of sodium chloride presented the highest concentration of 0.83 micromols $100 \mathrm{mg}^{-1} \mathrm{D} . \mathrm{W}$ followed by an overlap between $0.1 \% \times 30 \mathrm{mmol}^{-1}$ of $\mathrm{NaCl}$ $\left(0.78 \mu \mathrm{mol} 100 \mathrm{mg}^{-1} \mathrm{D} . \mathrm{W}\right)$.

Table 2. Effect of chemical mutagens DMS on average hydrogen peroxide of strawberries under saline stresses an in vitro.

\begin{tabular}{|c|c|c|c|c|c|}
\hline \multirow{2}{*}{$\begin{array}{l}\text { Mutagen } \\
\text { DMS (\%) }\end{array}$} & \multicolumn{4}{|c|}{ Salinity levels (mmol) } & \multirow{2}{*}{ Mean } \\
\hline & $\mathbf{0}$ & 30 & 60 & 90 & \\
\hline $\mathbf{0}$ & 0.44 & 0.43 & 0.42 & 0.44 & 0.43 \\
\hline 0.03 & 0.53 & 0.58 & 0.64 & 0.83 & 0.64 \\
\hline 0.06 & 0.42 & 0.71 & 0.44 & 0.60 & 0.54 \\
\hline 0.1 & 0.62 & 0.78 & 0.46 & 0.56 & 0.61 \\
\hline Mean & 0.50 & 0.62 & 0.49 & 0.61 & \\
\hline LSD $p \leq 0.05$ & \multicolumn{2}{|c|}{$\mathrm{DMS}=\mathbf{0 . 0 2}$} & Salt. $=0.01$ & \multicolumn{2}{|c|}{ DMS $\times$ Salt.$=0.03$} \\
\hline
\end{tabular}

While the interaction of $0.06 \%$ mutagen $\mathrm{X} 0$ and the interaction of $0.06 \times 60 \mathrm{mmol} \mathrm{l}^{-1}$ of $\mathrm{NaCl}$, the lowest concentration was 0.42 micromol $100 \mathrm{mg}^{-1} \mathrm{~d} . \mathrm{w}$ for each of the two interactions.

Catalase enzyme (AU min $^{-1} \mathrm{~g}^{-1}$ )

Table 3 shows that the mutagen levels differed significantly among treatments, the level $0.03 \%$ showed the highest concentration of Catalase enzyme, which was $19.53 \mathrm{AU}^{\mathrm{min}}{ }^{-}$
${ }^{1} \mathrm{~g}^{-1}$, then the level $0.1 \%\left(19.23\right.$ AU $\left.\min ^{-1} \mathrm{~g}^{-1}\right)$, the level $0.06 \%\left(17.75 \mathrm{AU} \min ^{-1} \mathrm{~g}^{-1}\right)$ while, control treatment was $16.35 \mathrm{AU}^{\mathrm{min}^{-1}} \mathrm{~g}^{-1}$ of Catalase enzyme. Level $30 \mathrm{mmol}^{\text {liter }}{ }^{-1}$ highest Catalase concentration was 19.38 AU $\mathrm{min}^{-1} \mathrm{~g}^{-1}$, then level $90 \mathrm{mmol}^{\text {liter }}{ }^{-1}(18.51 \mathrm{AU}$ $\left.\min ^{-1} \mathrm{~g}^{-1}\right)$, so the comparison was $(17.74 \mathrm{AU}$ $\min ^{-1} \mathrm{~g}^{-1}$ ), while the level $60 \mathrm{Mmol}$ showed the lowest Catalase concentration 17.23 $\mathrm{AU} \mathrm{min}{ }^{-1}$ $\mathrm{g}^{-1}$.

Table 3. Effect of chemical mutagens DMS on average strawberry Catalase under saline stress an in vitro.

\begin{tabular}{|cccccc|}
\hline Mutagen & \multicolumn{5}{c|}{ Salinity levels $(\mathrm{mmol})$} \\
DMS $(\%)$ & 0 & 30 & 60 & 90 & Mean \\
\hline 0 & 16.35 & 16.55 & 16.25 & 16.25 & 16.35 \\
0.03 & 18.20 & 18.55 & 19.70 & 21.65 & 19.53 \\
0.06 & 16.30 & 20.25 & 16.30 & 18.15 & 17.75 \\
0.1 & $\mathbf{2 0 . 1 0}$ & 22.15 & 16.65 & 18.00 & 19.23 \\
Mean & 17.74 & 19.38 & 17.23 & 18.51 & \\
LSD p $\leq$ 0.05 & DMS $=\mathbf{0 . 1 7}$ & Salt. $=\mathbf{0 . 1 7}$ & DMS $\times$ Salt. $=\mathbf{0 . 3 4}$ \\
\hline
\end{tabular}

Superoxide dismutase (IU $100 \mathrm{mg}^{-1}$ salinity levels in the concentration of the D.W)Table 4 indicates that the mutagen levels showed significant differences, the level $0.03 \%$ indicated the highest concentration of Superoxide dismutase, 116.8 IU $100 \mathrm{mg}^{-1}$ D.W, then the level $0.1 \%\left(99.8 \mathrm{IU} 100 \mathrm{mg}^{-1}\right.$ D.W), the level $0.06 \%\left(99.0100 \mathrm{IU} 100 \mathrm{mg}^{-1}\right.$ D.W), the comparison treatment presented 81.4100 IU $100 \mathrm{mg}^{-1}$ d.w of Superoxide dismutase. Also, it was noticed from the table that there were significant differences between Superoxide dismutase enzyme, as the level of $30 \mathrm{mmol}^{-1}$ showed the highest concentration of Superoxide dismutase, which was 114.0100 IU $100 \mathrm{mg}^{-1} \mathrm{~d} . \mathrm{w}$, then the level $90 \mathrm{mmol} \mathrm{L}^{-1}$

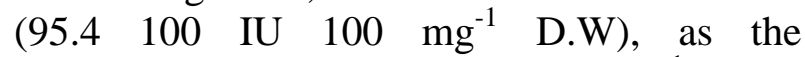
comparison was (94.3 $100 \mathrm{IU} 100 \mathrm{mg}^{-1}$ D.W), while the $60 \mathrm{mmol}$ levels gave the lowest concentration of Superoxide dismutase 93.3 $100 \mathrm{IU} 100 \mathrm{mg}^{-1}$ D.W. 
Table 4. Effect of chemical mutagens DMS on average SOD enzyme for strawberry under saline stress an in vitro.

\begin{tabular}{|cccccc|}
\hline Mutagen & \multicolumn{5}{c|}{ Salinity levels (mmol) } \\
DMS (\%) & 0 & 30 & 60 & 90 & Mean \\
\hline 0 & 81.4 & 81.6 & 81.5 & 81.2 & 81.4 \\
0.03 & 100.7 & 111.0 & 119.4 & 136.2 & 116.8 \\
0.06 & 81.7 & 125.8 & 81.8 & 106.6 & 99.0 \\
0.1 & 113.5 & 137.6 & 90.6 & 57.7 & 99.8 \\
Mean & 94.3 & 114.0 & 93.3 & 95.4 & \\
LSD p $\leq$ 0.05 & \multicolumn{7}{c}{ DMS $=\mathbf{9 . 9 3}$ Salt. $=\mathbf{9 . 9 3}$} & DMS $\times$ Salt. $=\mathbf{1 9 . 8 7}$ \\
\hline
\end{tabular}

From Table 4, it obvious that there were significant differences between the interactions of the two factors in the concentration of the superoxide dismutase enzyme. An interaction of $0.1 \%$ of the mutagen $\mathrm{X} 30 \mathrm{mmol} \mathrm{L}^{-1}$ of sodium chloride showed the highest concentration of $137.6 \mathrm{IU} 100 \mathrm{mg}^{-1} \mathrm{D} . \mathrm{W}$, followed by an interaction between $0.03 \% \mathrm{X}$ $90 \mathrm{mmol} \mathrm{L}^{-1}$ Sodium Chloride 136.2 IU 100 $\mathrm{mg}^{-1}$ D.W. While the interaction $0.1 \%$ of the mutagen $\mathrm{X} 90 \mathrm{mmol} \mathrm{L}^{-1}$ of $\mathrm{NaCl}$, the lowest concentration of the enzyme was 57.7 IU 100 $\mathrm{mg}^{-1}$ D.W.

\section{Chlorophyll $a\left(\mathrm{mg} \mathrm{g}^{-1}\right)$}

Table 5 shows that the mutagen levels differed significantly among them, as the comparison treatment revealed the highest concentration of chl $a$ was $35.75 \mathrm{mg} \mathrm{g}^{-1}$, then the level $0.06 \%$ (31.62 $\mathrm{mg} \mathrm{g}^{-1}$ ), while the two levels of 0.03 and $0.1 \%$ was $\left(29.75 \mathrm{mg} \mathrm{g}^{-1}\right)$ for each. In addition, it was noted from the table that there were significant differences between salinity levels in the concentration of $\operatorname{chl} a$, the results of control treatment were the highest concentration of chl $a$, which was $33.0 \mathrm{mg}$ gram $^{-1}$, then the level $60 \mathrm{mmol} \mathrm{l}^{-1}\left(32.50 \mathrm{mg} \mathrm{g}^{-}\right.$ $\left.{ }^{1}\right)$, however, the level was $90 \mathrm{mmol} \mathrm{L}^{-1}(31.12$ $\mathrm{mg} \mathrm{g}^{-1}$ ), although the level of $30 \mathrm{mmol}$ showed the lowest concentration of chlorophyll-a $30.25 \mathrm{mg} \mathrm{g}^{-1}$. Table 5, presented that there were significant differences between the interactions of the two factors in the concentration of chl $a$. Interaction of $0 \%$ of

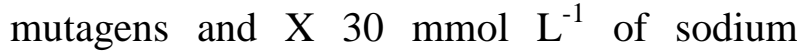
chloride was the highest concentration 37.50 $\mathrm{mg} \mathrm{g}^{-1}$, followed by an interaction between $0 \%$ and $\mathrm{x} 90 \mathrm{mmol} \mathrm{L}^{-1}$ of $\mathrm{NaCl}$ that reached 36.00 $\mathrm{mg} \mathrm{g}^{-1}$. Even though the interaction $0.06 \%$ of the mutagen and $\mathrm{X} 30 \mathrm{mmol} \mathrm{L}^{-1}$ of $\mathrm{NaCl}$ were the lowest concentration of $26.50 \mathrm{mg} \mathrm{g}^{-1}$.

Table 5. Effect of chemical mutagens DMS on average chlorophyll-a of strawberries under saline stresses an in vitro

\begin{tabular}{|cccccr|}
\hline Mutagen & \multicolumn{5}{c|}{ Salinity levels (mmol) } \\
DMS (\%) & 0 & 30 & 60 & 90 & Mean \\
\hline 0 & 35.00 & 37.50 & 34.50 & 36.00 & 35.75 \\
0.03 & 30.50 & 28.50 & 31.50 & 28.50 & 29.75 \\
0.06 & 35.50 & 26.50 & 35.00 & 29.50 & 31.62 \\
0.1 & 31.00 & 28.50 & 29.00 & 30.50 & 29.75 \\
Mean & 33.00 & 30.25 & 32.50 & 31.12 & \\
LSD p $\leq$ 0.05 & \multicolumn{2}{c}{ DMS $=\mathbf{1 . 1 2}$} & Salt. $=\mathbf{1 . 1 2}$ & DMS $\times$ Salt. $=\mathbf{2 . 2 3}$ \\
\hline
\end{tabular}

\section{Chlorophyll b $\left(\mathrm{mg} \mathrm{g}^{-1}\right)$}

Results in Table 6 show that the mutagen levels differed significantly, the control treatment showed the highest concentration of chlorophyll b, which was $23.38 \mathrm{mg} \mathrm{g}^{-1}$, then the level $0.06 \%\left(19.50 \mathrm{mg} \mathrm{g}^{-1}\right)$, and then level $0.1 \%\left(18.0 \mathrm{mg} \mathrm{g}^{-1}\right)$, while the level $0.03 \%$ was given $17.5 \mathrm{mg} \mathrm{g}^{-1}$ the lowest concentration of chl $b$. Similarly, it was noticed from the table that there were significant differences between the salinity levels in the concentration of chl b, the control treatment and the level $60 \mathrm{mmol} \mathrm{L}$ ${ }^{1}$ was the highest concentration of $\operatorname{chl} b$ which was $20.62 \mathrm{mg} \mathrm{g}^{-1}$ for each, then the level 90 $\mathrm{mmol} \mathrm{l}^{-1}\left(19.12 \mathrm{mg} \mathrm{g}^{-1}\right)$. The level of $30 \mathrm{mmol}$ $\mathrm{L}^{-1}$ revealed the lowest concentration of chlorophyll b, which was $18.00 \mathrm{mg}^{-1}$. there were significant differences between the interactions of the two factors in the concentration of chlorophyll $b$ (Table 6). Interaction of $0 \%$ of mutagens and X $30 \mathrm{mmol}$ $\mathrm{L}^{-1}$ of sodium chloride were the highest concentration of $25.00 \mathrm{mg} \mathrm{g}^{-1}$, followed by an interaction between $0.06 \%$ and $\mathrm{X} 0$ of sodium chloride $\left(24.00 \mathrm{mg} \mathrm{g}^{-1}\right)$. However, interference $0.06 \%$ of mutagens and $\mathrm{X} 30 \mathrm{mmol} \mathrm{L}^{-1}$ of 
$\mathrm{NaCl}$ was the lowest concentration of $13.50 \quad \mathrm{mg} \cdot \mathrm{g}^{-1}$.

Table 6. The effect of chemical mutagens, DMS, on average chlorophyll b of strawberries under saline stress, in vitro

\begin{tabular}{|cccccc|}
\hline Mutagen & \multicolumn{5}{c|}{ Salinity levels $(\mathrm{mmol})$} \\
DMS (\%) & 0 & 30 & 60 & 90 & Mean \\
\hline 0 & 22.50 & 25.00 & 22.50 & 23.50 & 23.38 \\
0.03 & 18.00 & 16.00 & 20.00 & 16.00 & 17.50 \\
0.06 & 24.00 & 13.50 & 22.50 & 18.00 & 19.50 \\
0.1 & 18.00 & 17.50 & 17.50 & 19.00 & 18.00 \\
Mean & 20.62 & 18.00 & 20.62 & 19.12 & \\
LSD p $\leq 0.05$ & \multicolumn{2}{c}{ DMS $=1.13$} & Salt. $=1.13$ & DMS $\times$ Salt. $=\mathbf{2 . 2 7}$ \\
\hline
\end{tabular}

Total chlorophyll $\left(\mathbf{m g}^{-1} \mathbf{g}\right) \quad$ presented the lowest total chlorophyll The control treatment showed the highest concentration of $70.50 \mathrm{mg} \mathrm{g}^{-1}$. there were concentration of total chlorophyll, which significant differences between the interactions reached $79.0 \mathrm{mg}^{-1}$, then the level $0.06 \%(72.00$ of the two factors in the total chlorophyll $\left.\mathrm{mg} \mathrm{g}^{-1}\right)$, followed by level $0.03 \%\left(70.50 \mathrm{mg} \mathrm{g}^{-} \quad\right.$ concentration, as an interaction of $0 \%$ of the ${ }^{1}$ ), whereas the level $0.1 \%$ gave the lowest mutagen and $X 30 \mathrm{mmol} \mathrm{l}^{-1}$ of sodium chloride concentration of 70.12. $\mathrm{mg} \mathrm{g} \mathrm{g}^{-1}$ of total was the highest concentration of $80.50 \mathrm{mg} \mathrm{g}^{-1}$, chlorophyll (table 7). There were significant followed by an interaction of $0 \% \mathrm{X} 60 \mathrm{mmol} \mathrm{l}^{-}$ differences between salinity levels on the total ${ }^{1}$ and $0 \% 90 \mathrm{X} \mathrm{mmol}^{-1}$ of sodium chloride chlorophyll concentration, the level $60 \mathrm{mmol} \mathrm{l}^{-}$were $79.00 \mathrm{mg} \mathrm{g}^{-1}$ for each. The interaction 1 indicated the highest total chlorophyll $0.03 \%$ of the mutagen and $\mathrm{x} 60 \mathrm{mmol}^{-1}$ of concentration of $74.75 \mathrm{mg} \mathrm{g}^{-1}$, then the control sodium chloride the lowest concentration of treatment $\left(74.38 \mathrm{mg} \mathrm{g}^{-1}\right)$, and level $90 \mathrm{mmol} \mathrm{l}^{-1}$ $\left(72.00 \mathrm{mg} \mathrm{g}^{-1}\right)$. While the level of $30 \mathrm{mmol}^{-1}$ $47.50 \mathrm{mg} \mathrm{g}^{-1}$.

Table 7. Effect of chemical mutagens DMS on mean total chlorophyll of strawberries under saline stress in vitro

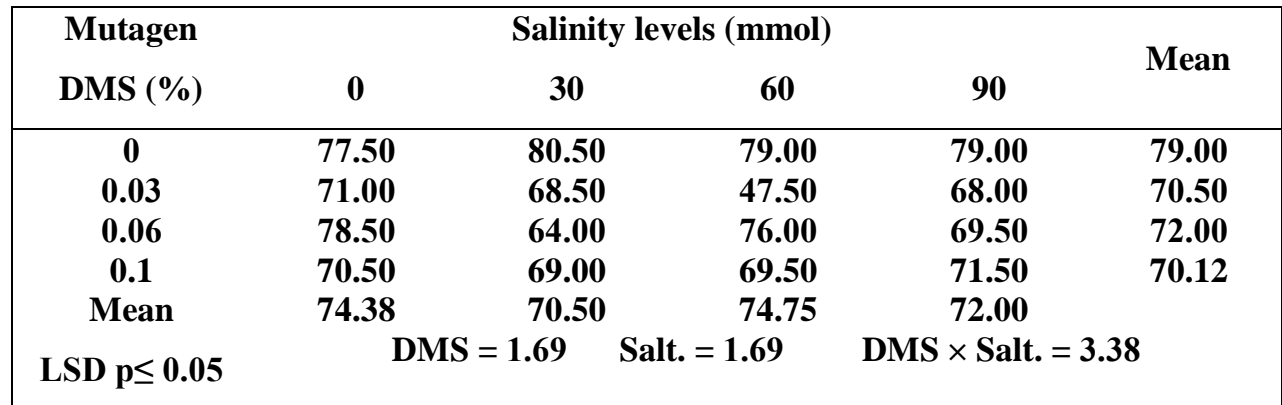

The chemical mutagen Dimethyl sulphate was very effective in increasing the concentration of proline, hydrogen peroxide, catalase enzyme and Superoxide dismutase, which indicates that this chemical compound increased the antioxidant activity which led to an increase in these biochemical indicators. Dimethyl sulphate is considered one of the mutants that lead to stimulating mutations and abnormalities in a chromosome and other genetic mutations in living organisms, which affect some biochemical characteristics, that is, the activation of plant metabolism resulting from the use of the mutagen (20). The reason may be attributed to the result that the mutagen Dimethyl sulphate increases the rate of plant cell activity, which is reflected in some biochemical characteristics (22). This response may be due to rearrangement of the genetic material due to the effect of the chemical mutagen Dimethyl sulphate, which causes an increase in the rate of cell metabolism and elongation, which affects some biochemical and physiological characteristics (19). The reason for the increased efficiency of Catalase is the result of increased active oxygen species such as hydrogen peroxide and hydroxyl radical, the mutagen Dimethyl sulphate increased most of the traits in this study compared to untreated plants and may support a mechanism these plants (21). The mutagen was applied in this study led to a decrease in the level of chlorophyll $a, b$, and the total of chlorophyll. The reason may be attributed to 
the fact that the mutagen impaired the proteinpigment-lipid complex, and reduced the activity of the enzyme chlorophyllase (32). The slight decrease in the values of some traits outside the living body as a result of increased salinity levels may be attributed to the salinity inhibits plant growth in three main ways, which is the water deficit arising from the negative water stress (high osmotic pressure) for the culture medium, the ionic toxicity that related to the increase in the absorption of sodium or chloride, the other way is the ionic imbalance when the increase of sodium or chloride ions causes a decrease in the absorption of potassium, calcium, nitrates, or phosphorous, or the internal distribution of these substances is disturbed (7). Therefore, an increase in some biochemical markers such as Catalase may be due to the toxic effect of increased salt tension (30). It may also be attributed that an increase in the concentration of sodium chloride may rise the oxidation of lipids in cell membranes, which is an indication of the breakdown of these membranes, which leads to an increase in the permeability of the plasma membrane or loss of its property (9). The increase in some biochemical markers with an increase in salinity levels, such as proline, hydrogen peroxide, Catalase, and Superoxide dismutase could be due to the increase in antioxidants led to iron deficiency as well as the disruption of the electron transport chain in the chloroplast (16). Another reason the increase in sodium or chloride ions, which increased the activity of some enzymes, including Catalase and Peroxidase (4). The increase in some biochemical indicators in high levels of sodium chloride due to salt tension that attributed to the osmotic effect and the negative ionic effect caused by salinity by increasing the concentration of sodium chloride as it affects the expansion and growth of cells and the decrease in the amount of water entering into cells. The decrease in the water stress of the culture medium as a result of the increase in salt concentration, which reduces the swelling pressure of the cell, thus impedes the biochemical processes inside the cell for a division of the cell, which causes an increase in oxidation enzymes and hydrogen peroxide, the salt tension caused an increase in the accumulation of proline (3). The results of the study indicated that the salt tension had an opposite effect on specific and total chlorophyll, while it had a positive effect on the proline content, the activity of Catalase, Superoxide dismutase and hydrogen peroxide. The reason could be due to there is a positive relationship between an increase in salinity and an increase in biochemical indicators due to an increase in free radicals. These indicators increase to reduce the effect of free radicals due to the increase in toxic ions in plant cells (13). The reason for the decrease in chlorophyll under salt tension is attributed to the disturbance of the activity of the second photosystem and the Thylakoid membrane with its damaged pigments due to the formation of free radicals or oxidation compounds under salt tension (12). The reason may be attributed to the disruption of many physiological processes, enzyme activity, and photosynthesis rate due to the malfunction of the stomata under salt tension, which changes the gas exchange and causes damage to the plant pigments due to the production of quantities of free oxygen groups (23), this reduces the chlorophyll and carotene content under salt stress (8).

\section{CONCLUSION}

The DMS affected some characters which $0.03 \%$ effectively improved proline, $\mathrm{H}_{2} \mathrm{O}_{2}$, CAT, and SOD, whereas chlorophyll was decreased. Furthermore, the low concentration of $\mathrm{NaCl}$ increased content of proline, $\mathrm{H}_{2} \mathrm{O}_{2}$ and SOD in plantlets using in vitro culture. Salinity at $60 \mathrm{Mm}$ improved total chlorophyll. Biochemical indices were very informative to assess dimethylsulfate's effect on plantlets of strawberry under saline-stress in vitro.

\section{REFERENCES}

1. Adak, N., and L. Kaynak, 2016. Improvement of strawberry (Fragaria $x$ ananassa) through induced mutations and in vitro Culture. Intern. J. Agric. Innov.Res. 5(2): 242-246

2.M Aladina, O. N., S. V. Akimova, I. N. Buyanov, and S. S. Yasir, 2014. Application of ecogel in in vitro adaptation of raspberry plants to non-sterile conditions. Acad. Sci. Probl. Achiev. pp. 130-130 (in Russian).

3. Al-Anzi, B. N., and G. B. Al-abbasi, 2019. Effect of salicylic acid and putrescine on 
growth of strawberry (Fragaria ananassa Duch) cultures grown under salt stress in vitro culture. Stent. 3. Kerbala univ. 17(3):1-14

4. Alhasnawi, A. N., A. A. Kadhimi, A. R. Ibrahim, I. Anizan, M. Azhar, F. Doni, M. Wan, and R. Che, 2014. Salinity tolerant enhancement, tissue culture in vitro biochemical procedures. J. Plant Biol. Res. 3(2): 51-64

5. Al-Mohammadi, S. M., and F. M. AlMohammadi, 2012. Statistics and Experimental Design. Dar Osama for publishing. Amman, Jordan

6. Anuradha, S. K. S., A. K. Poonia, S. Kajla, and S. Bhat, 2016. Production of strawberry plant by in vitro propagation. Res. Crops. 17(3): 545-549

7. Assem, S. K., E. H. A Hussein, H. A. Hussein, and S. B. Awaly, 2010. Transformation of the salt-tolerance gene BIGST into egyptian maize inbred lines. Arab J. Biotechnol. 13(1): 99-114.

8. Cardeñosa,V., E. Medrano, P. Lorenzo, M. C. Sanchez-Guerrero, F. Cuevas, I. Pradas, and J. M Moreno-Rojas, 2015. Effects of salinity and nitrogen supply on the quality and healthrelated compounds of strawberry fruits (Fragariax ananassa cv. Primoris). J. Sci. Food Agric. 95(14): 2924-2930

9. Chai, T. T., N. M. Fadzillah, M. Kusnan, and M. Mahmood, 2005. Water stress-induced oxidative damage and antioxidant responses in micropropagated plantlets. Biolog.Plantar. 49(1):153-156

10. Dawood, Z. A., A. H Al-Alaf, and R. H Al-Sultan. 2010. Effect of foliar application of boron on growth, flowering and yield of strawberry. Iraqi J. Agric. Sci. 41(3): 89-99

11. Fierascu, R. C., G. Temocico, I. Fierascu, A. Ortan, and N. E. Babeanu. 2020. Fragaria genus: chemical composition and biological activities. Molec. 25(3):498-520

12. Gomes, M. A. D. C., I. A. Pestana, C. Santa-Catarina, R. A. Hauser-Davis, and M. S. Suzuki, 2017. Salinity effects on photosynthetic pigments, proline, biomass and nitric oxide in Salvinia auriculata Aubl. Acta Limnol Brasil. 29(9): 1-13

13. Hussein, E. A., A. Y. El-Kerdany, and M. K. Afifi, 2016. Effect of drought and salinity stresses on two strawberry cultivars during their regeneration in vitro. Intern. J. Inn. Sci. Engin. Technol. 4(8): 83-93

14. Ibrahim, M. A., H. A. Al-Taha, and Z. A. Saaid, 2013. Propagation of strawberry via in vitro adventitious shoot formation technique. Iraqi J. Agric. Sci. 44(1): 69-80

15. Jamalian, S., M. Gholami, and M. EsnaAshari, 2013. Abscisic acid-mediated leaf phenolic compounds, plant growth and yield is strawberry under different salt stress regimes. Theoret. Exp. Plant Physiol. 25(4): 291-299

16. Kaya, C., N. A. Akram, and M. Ashraf. 2019. Influence of exogenously applied nitric oxide on strawberry (Fragariax ananassa) plants grown under iron deficiency and/orsaline stress. Physiolog. Plantar. 165(2): 247-263

17. Khalil, N. H. 2016. Crown diameter, chilling, and gibberellic acid interactions influence growth and reproductive of strawberry cv. festival. Iraqi J. Agric. Sci. 47(2): 672-676

18. Kresty, L. A., M. A. Morse, C. Morgan, P. S. Carlton, J. Lu, A. Gupta, M. Blackwood, and G.D. Stoner, 2001. Chemoprevention of esophageal tumorigenesis by dietary administration of lyophilized black raspberries. Cancer Res. 61(16): 6112-6119 19. Mostafa, G. G., and M. F. Abou Alhamd, 2016. Effect of dimethyl sulphate on the growth, induction of mutations and their identification by peroxidase isozyme in tecoma stans. Int. J. Plant breed. Genet. 10: 91-97

20. Mostafa, G. G., and M. F. Abou Alhamd, 2015. Induction of salt tolerant mutants of Foeniculum vulgare by dimethyl sulphate and their identification using protein pattern and ISSR markers. Alex. J. Agric. Res. 60(2): 95109

21. Mostafa, G. G. 2009. Effect of dimethyl sulphate on the growth and some chemical compositions of Balanites aegyptiaca, Delile. Alex. J. Agric. Res. 54(3): 81-89

22. Mostafa, G.G. 2015. Effect of some chemical mutagens on the growth, phytochemical composition and induction of mutations in Khaya senegalensis. Int J Plant Breed Genet. 9(2): 57-67

23. Mozafari, A. A, S. Dedejani, and N. Ghaderi, 2018. Positive responses of 
strawberry (Fragariax ananassa Duch) explants to salicylic and iron nanoparticle application under salinity conditions. Plant Cell Tiss. Organ Cult. 134(2): 267-275

24. Murashige, T., and F. Skoog, 1962. A revised medium for rapid growth and bioassays with tobacco tissue cultures. Physiolog. Plantar. 15(3): 473-497

25. Murti, R. H., H. Y Kim, and Y. R. Yeoung, 2013. Effectiveness of gamma ray irradiation and ethyl methane sulphonate on in vitro mutagenesis of strawberry. Afr.J. Biotechnol. 12(30): 4803-4812

26. Neamah, S. I., I. A. Sarhan, O. N. AlShaye'a, 2018. Extraction and evaluation of the anti-inflammatory activity of six compounds of Marrubium vulgare L., Bioscience Research, 15(3): 2393-2400

27. Padmanabhan, P., A. Mizran, J. A Sullivan, and G. Paliyath, 2016. Strawberries. encyclopedia of food and health. 3(1): 193198.

28. Pasqualini, A. P. D. A., M. C. D., Santos, H. P. D. F. Fraga, and M., Quoirin, 2019. In vitro culture and diversity of endophytic fungi in Bambusa oldhamii. Pesquis. Agropecu. Trop. 49: 1-9

29. Penna, S., S. B. Vitthal, and P. V. Yadav, 2012. In vitro mutagenesis and selection in plant tissue cultures and their prospects for crop improvement. Bioremed. Biodiv Bioavail. 6:6-14
30. Seckin, B., I. Turkan, A. H. Sekmen, and C. Ozfidan, 2010. The role of antioxidant defense systems at differential salt tolerance of Hordeum marinum Huds. (sea barleygrass) and Hordeum vulgare L. (cultivated barley). Environ. Exp. Bot.69(1): 76-85

31. Shu, Q. Y., B. P. Forster, H. Nakagawa, and H. Nakagawa, 2012. Plant Mutation Breeding and Biotechnology. CAB International and FAO. Gutenberg Press Ltd. P595

32. Stivsev, M. V., S. A. Ponnamoreva, and E. A. Kuznetsova, 1973. Effect of salinization and herbicides on chlorophyllase activity in tomato leaves. Fiziol. Rast. 20: 62-65

33. Vasko, V., and V. Kyrychenko, 2016. Variability of valuable economic traits in $\mathrm{M}_{1}$ and $\mathrm{M}_{2}$ sunflower generations influenced by dimethyl sulfate and $\gamma$-rays. Agric. Sci. 23(4): 168-177

34. Vasko, V. O., and V. V. Kyrychenko, 2019. Induced mutagenesis for the creation of new starting material in sunflower breeding. Helia. 42(70):17-36

35. Zahedi, S. M., M. S. Hosseini, J. Abadía, and M. Marjani.2020. Melatonin foliar sprays elicit salinity stress tolerance and enhance fruit yield and quality in strawberry (Fragariax ananassa Duch). Plant Physiol. Biochem. 149:313-323. 